\title{
Effects of Variable Diuron on the Sugar Production and Enzyme Activity of Sugarcane Grown on Clay and Sandy Loam Soils in Puerto Rico
}

\author{
Alex G. Alexander 1
}

\section{INTRODUCTION}

The substituted urea Diuron ${ }^{2}$ is used extensively as a sugarcane herbicide, even though its mode of action and influence upon sugar formation remain obscure. Urea herbicides reportedly affect the Hill reaction (12,15, $18)^{3}$, sugar metabolism $(18,14)$, and ATP synthesis (15). In vitro studies in Puerto Rico disclosed abnormal enzyme behavior of ratoon cane some 25 months after soil treatment (1). Later experiments showed that traces of Diuron competitively inhibited sucrose synthesis from fructose and glucose1-phosphate (2). Recent sand-culture studies at this Station demonstrated conclusively that sucrose formation is depressed by Diuron, and that the herbicide's effect is greatly dependent upon nitrogen supply (10).

While evidence suggests that Diuron retards sucrose synthesis, some workers believe that total yield is increased by eliminating the competition of weeds for water and nutrients. Soil type and water supply are unknown factors in determining Diuron-enzyme relationships in the field. It has also been suggested that Diuron affects sugar production only in young cane. Indeed, most of the enzyme-herbicide work in Puerto Rico has been conducted with immature greenhouse material or young ratoon samples from the field. This paper summarizes a 16-month study of Diuron relationships with sugars and enzymes of cane grown on clay and sandy loam soil.

\section{MATERIALS AND METHODS}

Sugarcane of the variety P.R. 980 was grown in concrete greenhouse benches containing Fajardo clay and San Antón sandy loam. Each bench measured 92 by 52 inches, was surrounded by 6 -inch walls, and provided with adequate subdrainage. Soil extended to a depth of 20 inches. Threeeye cuttings were planted about 4 inches deep in each of two parallel trenches extending lengthwise through the plots. Diuron levels equivalent to $0,2,6$, and 18 pounds per acre were applied as a pre-emergence spray using the wettable powder suspended in water. Application was made with a Hudson hand-sprayer. Cardboard baffles were placed around each plot during treatment to minimize drifting of spray.

1 Plant Physiologist, Agricultural Experiment Station, Mayagüëz Campus, University of Puerto Rico, Rio Piedras, P.R.

2 3-(3,4-dichlorophenyl)-1,1-dimethylurea.

- Italic numbers in parentheses refer to Literature Cited, pp. 138-9. 
All plots were watered quite heavily with about 1.5 inches per week. The cane was sprayed for insects at intervals of 2 weeks. A single fertilizer treatment was given 1 month after planting. The latter was equivalent to 500 pounds of ammonium sulfate, 440 pounds of treble superphosphate, and 330 pounds of potassium chloride per acre. The components were thoroughly mixed and then sidedressed along one side of each row.

Cane samples were harvested for sugar and enzyme analyses at 2,6, and 12 months. All remaining cane was cut at 12 months. A final set of samples was later taken from the first ratoon crop at 16 months. Leaves +1 to +4 and immature storage tissue (meristem) were frozen in a mixture of Dry Ice and acetone, lyophilized, and ground to a fine powder in accordance with procedures described previously ( 3 ). Clarified water extracts of the plant powder were analyzed for total ketose by the method of Roe (16), and for sucrose by the modification of Cardini et al. (11). Fructose was estimated by subtracting sucrose values from those of total ketose. Protein was precipitated from water extracts, as described earlier (3), and employed for enzyme assay without dialysis. Phosphatases hydrolizing $\beta$-glycerophosphate $(\beta-G P)$, adenosine triphosphate (ATP), and glucose-1-phosphate (G-1-P) were analyzed by techniques described previously (4). Other enzymes measured were amylase $(6)$, starch phosphorylase (9), polyphenol oxidase $(8)$, peroxidase $(7)$, and invertase $(5)$. Protein content of enzyme preparations was determined colorimetrically by the method of Sutherland et al. (17). Enzyme action was recorded as specific activity (activity units per milligram of protein). Diuron content of leaves was measured by the method of Young and Gortner (19), using a 15-minute development period for azo dye formation.

\section{RESULTS AND DISCUSSION}

\section{DIURON SUPPRESSION OF SUGARS}

Diuron severely depressed both leaf and meristem sucrose content of 2-month-old plants (table 1, figure 1). The effect was clearly evident at both the 6- and 18-pound-per-acre levels. As shown by table 1, the decline of total ketose production reflects a suppression of total sugar synthesis rather than increased sucrose inversion or an interference with sucrose formation.

At 6 months the Diuron effect was no longer evident in leaves, although meristem tissues still reflected a strong herbicide suppression of sucrose (table 2). Total ketose content was now declining in both leaf and storage tissues in response to 18 pounds of Diuron. By 12 months there was no consistent Diuron effect upon sucrose (table 3). Finally, at 16 months, the first-ratoon samples actually revealed sugar increases in immature storage 
TABLE 1.-Leaf-sugar content of 2-month-old sugarcane grown on clay and sandy loam soils trealed with Diuron ${ }^{1}$

\begin{tabular}{l|l|c|c|c|c|c}
\hline \multirow{2}{*}{ Soil } & \multicolumn{2}{|c|}{ Sugar } & \multicolumn{2}{|c|}{ Results under Diuron treatment (lb./ acre) } & \multirow{2}{*}{ Mean } \\
\cline { 2 - 5 } & & 0 & 2 & 6 & 18 & \\
\hline Clay & Total ketose & 91.2 & 81.4 & 86.0 & 64.6 & 80.8 \\
& Sucrose & 56.5 & 51.5 & 47.8 & 37.3 & 48.1 \\
& Fructose & 34.7 & 34.2 & 34.5 & 27.4 & 32.7 \\
& & & & & & \\
& Total ketose & 81.0 & 74.3 & 63.5 & 50.2 & 67.2 \\
& Sucrose & 49.2 & 44.8 & 36.4 & 23.7 & 38.5 \\
& Fructose & 31.9 & 29.2 & 27.2 & 26.5 & 28.7 \\
\hline
\end{tabular}

1 Sugars are expressed as milligrams per gram of dry weight. Each figure represents the mean of 4 replicates.
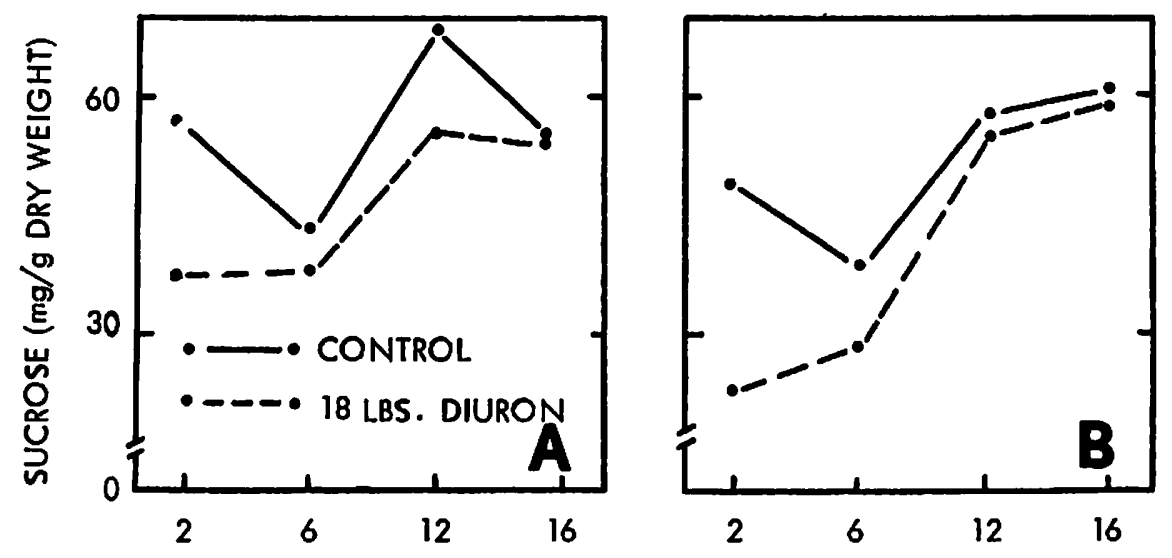

\section{AGE OF CANE (MONTHS)}

Frg. 1.-Leaf sucrose content of sugarcane grown on soils treated with 18 pounds of Diuron per acre: A, Fajardo clay; B, San Antón sandy loam.

tissues in response to the 2- and 6-pound Diuron treatments (table 4). Fresh weights taken at this time showed no significant effect of Diuron upon overall growth. Thus a striking Diuron-sucrose relationship noted early in the study failed to persist as a predictable, residual herbicide effect. Possibly the plants had made biochemical compensations for the presence of Diuron, such as mobilization of endogenous compounds to compete with the herbicide for active enzyme sites.

However, leaf analyses indicate that Diuron literally disappeared from the plants sometime after the 2-month harvest (table 5). At 16 months 
TABLE 2.-Leaf and meristem sugar content of 6-month-old sugarcane grown on clay and sandy loam soils treated with Diuron'

\begin{tabular}{|c|c|c|c|c|c|c|}
\hline \multirow{2}{*}{ Soil } & \multirow{2}{*}{ Sugar } & \multicolumn{4}{|c|}{ Leaf sugars as affected by Diuron (lb./ acre) } & \multirow{2}{*}{ Mean } \\
\hline & & $\mathbf{0}$ & 2 & 6 & 18 & \\
\hline \multirow{3}{*}{ Clay } & Total ketose & 75.8 & 81.7 & 82.3 & 64.7 & \multirow{7}{*}{$\begin{array}{l}76.1 \\
44.2 \\
31.9 \\
\\
57.6 \\
34.1 \\
23.2\end{array}$} \\
\hline & Sucrose & 43.2 & 49.1 & 45.3 & 39.0 & \\
\hline & Fructose & 32.6 & 32.6 & 37.0 & 25.7 & \\
\hline \multirow{4}{*}{ Sandy loam } & \multirow{4}{*}{$\begin{array}{l}\text { Total ketose } \\
\text { Sucrose } \\
\text { Fructose }\end{array}$} & 67.1 & 65.1 & 49.2 & 49.0 & \\
\hline & & 38.4 & 37.7 & 31.1 & 29.0 & \\
\hline & & 28.4 & 27.3 & 18.1 & 19.9 & \\
\hline & & \multicolumn{4}{|c|}{$\begin{array}{l}\text { Meristem sugars as affected by } \\
\text { Diuron (b./acre) }\end{array}$} & \\
\hline \multirow[t]{3}{*}{ Clay } & \multirow{3}{*}{$\begin{array}{l}\text { Total ketose } \\
\text { Sucrose } \\
\text { Fructose }\end{array}$} & 362 & 333 & 377 & 305 & \multirow{3}{*}{$\begin{array}{l}344 \\
151 \\
175\end{array}$} \\
\hline & & 180 & 170 & 141 & 115 & \\
\hline & & 182 & 163 & 166 & 189 & \\
\hline \multirow[t]{3}{*}{ Sandy loam } & Total ketose & 333 & 312 & 284 & 260 & 297 \\
\hline & Sucrose & 139 & 90 & 67 & 51 & 87 \\
\hline & Fructose & 228 & 255 & 267 & 226 & 244 \\
\hline
\end{tabular}

1 Sugars are expressed as milligrams per gram of dry weight. Each figure represents the computed mean of 4 replicates.

TAULE 3.-Leaf and meristem sugar content of 12-month-old sugurcane grown on clay and sandy loam soils treated with Diuron ${ }^{1}$

\begin{tabular}{|c|c|c|c|c|c|c|}
\hline \multirow{2}{*}{ Soil } & \multirow{2}{*}{ Sugar } & \multicolumn{4}{|c|}{ Leal sugars as affected by Diuron (lb./acre) } & \multirow{2}{*}{ Mean } \\
\hline & & o & 2 & 6 & 18 & \\
\hline Clay & $\begin{array}{l}\text { Total ketose } \\
\text { Sucrose } \\
\text { Fructose }\end{array}$ & $\begin{array}{l}87.9 \\
71.2 \\
16.7\end{array}$ & $\begin{array}{l}84.3 \\
65.7 \\
18.6\end{array}$ & $\begin{array}{l}82.8 \\
67.4 \\
15.3\end{array}$ & $\begin{array}{l}71.8 \\
58.4 \\
13.4\end{array}$ & $\begin{array}{l}81.7 \\
65.7 \\
16.0\end{array}$ \\
\hline \multirow[t]{2}{*}{ Sandy loam } & $\begin{array}{l}\text { Total ketose } \\
\text { Sucrose } \\
\text { Fructose }\end{array}$ & $\begin{array}{l}74.0 \\
58.8 \\
15.3\end{array}$ & $\begin{array}{r}69.0 \\
61.0 \\
8.0\end{array}$ & $\begin{array}{l}84.7 \\
61.7 \\
22.9\end{array}$ & $\begin{array}{l}69.9 \\
55.7 \\
14.2\end{array}$ & \multirow[t]{2}{*}{$\begin{array}{l}74.4 \\
59.3 \\
15.1\end{array}$} \\
\hline & & \multicolumn{4}{|c|}{$\begin{array}{l}\text { Meristem sugars as affected by } \\
\text { Diuron (b./acre) }\end{array}$} & \\
\hline Clay & $\begin{array}{l}\text { Total ketose } \\
\text { Sucrose } \\
\text { Fructose }\end{array}$ & $\begin{array}{l}259 \\
81.2 \\
178\end{array}$ & $\begin{array}{l}281 \\
88.6 \\
192\end{array}$ & $\begin{array}{c}272 \\
72.4 \\
199\end{array}$ & $\begin{array}{c}246 \\
78.6 \\
167\end{array}$ & $\begin{array}{c}265 \\
80.2 \\
184\end{array}$ \\
\hline Sandy loam & $\begin{array}{l}\text { Total ketose } \\
\text { Sucrose } \\
\text { Fruetose }\end{array}$ & $\begin{array}{c}229 \\
68.0 \\
161\end{array}$ & $\begin{array}{l}223 \\
73.4 \\
149\end{array}$ & $\begin{array}{c}223 \\
75.2 \\
128\end{array}$ & $\begin{array}{c}224 \\
80.8 \\
143\end{array}$ & $\begin{array}{c}225 \\
74.4 \\
145\end{array}$ \\
\hline
\end{tabular}

1 Sugars are expressed as milligrams per gram of dry weight. Each figure represents the computed mean of 4 replicates. 
TABLE 4.-Leaf and meristem sugar content of 16-month-old sugarcane grown on clay and sandy loam soils treated with Diuron'

\begin{tabular}{|c|c|c|c|c|c|c|}
\hline \multirow{2}{*}{ Soil } & \multirow{2}{*}{ Sugar } & \multicolumn{4}{|c|}{ Leaf sugars as affected by Diuron (lb./acre) } & \multirow{2}{*}{ Mean } \\
\hline & & 0 & 2 & 6 & 18 & \\
\hline Clay & $\begin{array}{l}\text { Total ketose } \\
\text { Sucrose } \\
\text { Frtctose }\end{array}$ & $\begin{array}{l}74.0 \\
55.7 \\
18.4\end{array}$ & $\begin{array}{l}82.3 \\
59.2 \\
23.1\end{array}$ & $\begin{array}{l}75.0 \\
56.5 \\
18.5\end{array}$ & $\begin{array}{l}70.5 \\
54.9 \\
15.7\end{array}$ & $\begin{array}{l}75.5 \\
56.6 \\
18.9\end{array}$ \\
\hline \multirow[t]{2}{*}{ Sandy loam } & $\begin{array}{l}\text { Total ketose } \\
\text { Sucrose } \\
\text { Fructose }\end{array}$ & $\begin{array}{l}76.6 \\
61.3 \\
15.4\end{array}$ & $\begin{array}{l}76.1 \\
58.4 \\
17.8\end{array}$ & $\begin{array}{l}73.5 \\
56.7 \\
16.8\end{array}$ & $\begin{array}{l}78.2 \\
59.0 \\
19.2\end{array}$ & \multirow[t]{2}{*}{$\begin{array}{l}78.9 \\
58.9 \\
17.3\end{array}$} \\
\hline & & \multicolumn{4}{|c|}{$\begin{array}{l}\text { Meristem sugars as affected by } \\
\text { Diuron (lb./acre) }\end{array}$} & \\
\hline Clay & $\begin{array}{l}\text { Total ketose } \\
\text { Sucrose } \\
\text { Fructose }\end{array}$ & $\begin{array}{r}280 \\
74 \\
206\end{array}$ & $\begin{array}{r}327 \\
96 \\
230\end{array}$ & $\begin{array}{r}209 \\
82 \\
227\end{array}$ & $\begin{array}{r}331 \\
74 \\
257\end{array}$ & $\begin{array}{r}312 \\
82 \\
230\end{array}$ \\
\hline Sandy loam & $\begin{array}{l}\text { Total ketose } \\
\text { Sucrose } \\
\text { Fructose }\end{array}$ & $\begin{array}{r}285 \\
67 \\
218\end{array}$ & $\begin{array}{r}304 \\
93 \\
211\end{array}$ & $\begin{array}{r}297 \\
89 \\
208\end{array}$ & $\begin{array}{r}288 \\
65 \\
223\end{array}$ & $\begin{array}{r}294 \\
79 \\
215\end{array}$ \\
\hline
\end{tabular}

1 Sugars are expressed as milligrams per gram of dry weight. Each figure represents the computed mean of 4 replicates.

TABLE 5.-Leaf-Diuron content of sugarcane grown on clay and sandy loam soils given pre-emergence Diuron treatments 1

\begin{tabular}{l|c|c|c|c|c|c}
\hline \multirow{3}{*}{ Age of Canc } & Soil & \multicolumn{3}{|c|}{ Effects of treatment (lb. Diuron/acre) } & \multirow{2}{*}{ Mean } \\
\cline { 2 - 5 } & & 0 & 2 & 6 & 18 & \\
\hline 2 months & Clay & 4.3 & 5.8 & 8.0 & 32.0 & 12.5 \\
& Loam & 7.2 & 19.7 & 32.0 & 43.0 & 25.4 \\
& Clay & 0 & .9 & 1.3 & 1.7 & .9 \\
& Loam & 0 & 0 & 0 & 0 & 0 \\
\hline
\end{tabular}

1 Diuron is expressed as micrograms per gram of dry weight. Each figure represents the computed mean of 4 replicates.

little more than traces of the herbicide were entering leaf tissues. While no Diuron data are available for the 6 - and 12-month harvests, the implication is that insufficient Diuron remained to continue the initial sugar depression. Presumably our water applications, about 1.5 inches per week, successfully leached the Diuron from all plots. 


\section{EFFECTS OF SOIL TYPE ON DIURON-SUGAR RELATIONSHIP}

The reader will note in table 5 that Diuron was far more readily absorbed from loam than from clay at 2 months. At 16 months some small traces of the herbicide were still detectable in plants from the clay plots, while no Diuron could be found in plants grown on loam. The availability of Diuron to cane thus appears greatly dependent upon soil physical and chemical properties.

Differential absorption of Diuron from the two soil types is also reflected by sucrose values given in tables 1 and 2 . The greater herbicide absorption from loam was accompanied by more severe leaf sucrose losses on loam (table 1). At 6 months, both leaf and meristem sucrose decline was clearly more severe among the loam plots (table 2). There is little doubt that the higher Diuron accumulations took part in suppressing sucrose synthesis, and the capacity of Diuron to do this has been observed in both in vitro (2) and sand-culture experiments (10). Only at the 16-month harvest was sugar production approximately equal for the two soil types. By this time Diuron absorption from both soils had virtually ceased (table 5).

\section{DIURON-ENZYME RELATIONSHIPS}

Since heaviest Diuron absorption was detected early in the study, one might have expected to find significant enzyme-herbicide relationships during the first few months of growth. In reality, both soil type and increasing age of cane affected enzymes more clearly than did Diuron. However, at the 2-month harvest, Diuron clearly altered the behavior of phosphatase and ATP-ase, plus amylase, peroxidase, and starch phosphorylase (table 6). These effects generally confirm earlier observations the probable significance of which has been discussed in detail $(2,1)$. Leaf peroxidase plus the meristem enzymes amylase, invertase, polyphenol oxidase, and peroxidase all reflect sensitivity to Diuron at 6 months (table 7). At 12 and 16 months we still encountered abnormal behavior of amylase, invertase, and the oxidases (tables 8 and 9), although very little Diuron was found in tissues at 16 months. The almost total lack of consistent enzyme trends is perhaps accountable to indirect Diuron relationships, particularly the plants' efforts to counteract or compensate herbicide effects that have occurred months earlier. However, direct Diuron-enzyme relationships have been conclusively demonstrated by in vitro techniques (2).

\section{SOIL-ENZYME RELATIONSHIPS}

A most unexpected finding of this study was the striking effect of soil type on enzyme behavior during early periods of cane growth and development. Leaf-enzyme activity at the 2-month harvest was consistently lower from the loam plots, regardless of herbicide treatment (table 7). Starch 
phosphorylase was less than one-third as active among plants grown on sandy loam. At 6 months the meristem enzymes ATP-ase and polyphenol oxidase were severely suppressed in plants grown on loam, as compared with those grown on clay (table 7). However, at 12 months, only invertase was clearly responding to soil variables and, at 16 months, no broad activity differences could be attributed to soils.

It was not surprising that soil effects of some degree were observed. The

TABLE 6.-Mean prolein content, and specific-activity values for leaf enzymes, of 2-month-old sugarcane grown on clay and sandy loam soils treated with Diuron 1

\begin{tabular}{|c|c|c|c|c|c|c|c|c|c|c|}
\hline \multirow[b]{2}{*}{ Soil } & \multirow[b]{2}{*}{$\begin{array}{l}\text { Diuron } \\
\text { (lb./acre) }\end{array}$} & \multicolumn{8}{|c|}{ Effects of enzyme indicated } & \multirow[b]{2}{*}{ Enzyme mean } \\
\hline & & $\begin{array}{c}\text { Phos- } \\
\text { phatase }\end{array}$ & $\underset{\text { ase }}{\text { ATP- }}$ & $\begin{array}{l}\text { G-1- } \\
\text { Pase }\end{array}$ & Amylase & $\begin{array}{c}\text { Poly- } \\
\text { phenol } \\
\text { oxidase }\end{array}$ & $\begin{array}{c}\text { Peroxi- } \\
\text { dase }\end{array}$ & $\begin{array}{l}\text { Starch } \\
\text { phos- } \\
\text { phoryl- } \\
\text { ase }\end{array}$ & Protein 2 & \\
\hline \multirow{5}{*}{ Clay } & 0 & 35 & 49 & 10 & 150 & 5.8 & 55 & 57 & 2.7 & 51.7 \\
\hline & 2 & 39 & 57 & 10 & 174 & 4.6 & 72 & 45 & 3.1 & 57.2 \\
\hline & 6 & 35 & 53 & 9 & 178 & 5.4 & 56 & 50 & 3.1 & 55.2 \\
\hline & 18 & 41 & 58 & 10 & 219 & 5.4 & 66 & 65 & 3.0 & 66.3 \\
\hline & Mean & 38 & 54 & 10 & 180 & 5.3 & 62 & 54 & 3.0 & 57.6 \\
\hline \multirow{5}{*}{$\begin{array}{l}\text { Sandy } \\
\text { loam }\end{array}$} & 0 & 26 & 40 & 7 & 129 & 4.0 & 52 & 12 & 3.7 & 38.5 \\
\hline & 2 & 36 & 50 & 9 & 120 & 4.6 & 58 & 29 & 3.3 & 43.8 \\
\hline & 6 & 31 & 45 & 9 & 121 & 4.1 & 56 & 6 & 3.4 & 38.8 \\
\hline & 18 & 26 & 41 & 7 & 99 & 4.1 & 59 & 12 & 3.5 & 35.4 \\
\hline & Mean & 29 & 44 & 8 & 117 & 4.2 & 56 & 15 & 3.5 & 39.0 \\
\hline
\end{tabular}

1 Each figure represents the computed mean of 4 replicates.

2 Milligrams per gram of dry weight.

greater early availability of Diuron from loam could in itself account for considerable enzyme change. Yet the magnitude of enzyme change was puzzling, since only by relatively indirect means can soils affect enzyme action. Furthermore, while such features as ability to supply essential activators, cofactors, or inhibitors might ultimately find expression in enzyme behavior, we would expect these effects to be relatively permanent. There were no soil effects consistent throughout all harvests during the present study. Again it is suggested that the soil-enzyme responses were very indirect, reflecting the plants' continuing efforts to cope with some pecularity of the soil. It is possible that nutrient-uptake ratios varied sufficiently among the soil types to create completely different states of nutritional welfare within the respective plants. In this situation both the 
TABLE 7.-Mean prolein content, and specific-activity values for leaf and meristem enzymes, of 6-month-old sugarcane grown on clay and sandy loam soils trealed with Diuron 1

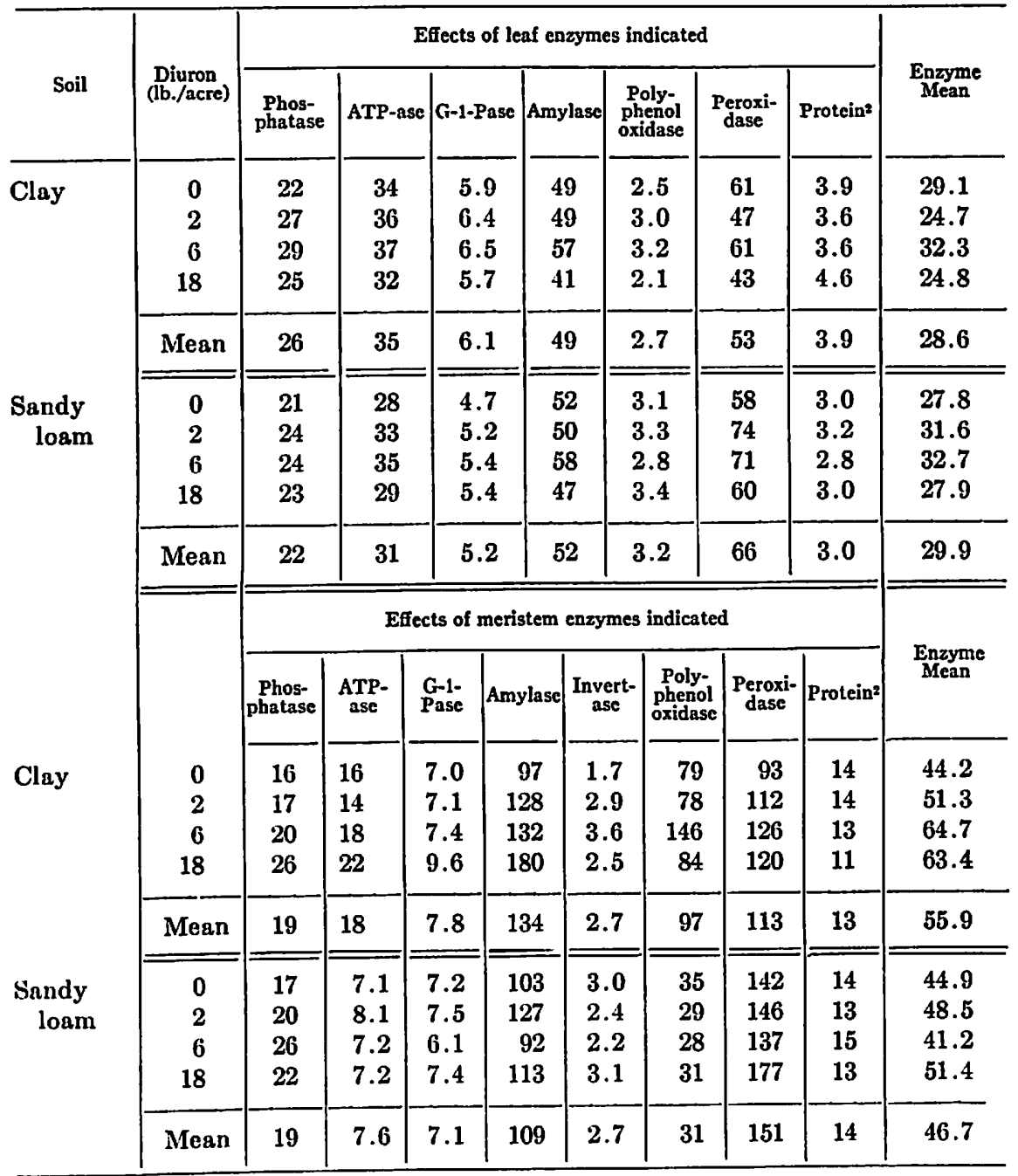

1 Each figure represents the computed mean of 4 replicates.

2 Milligrams per gram of dry weight.

enzyme roles and severity of demand made upon the enzymes might logically vary, but this still does not explain the lack of consistency for soil-enzyme relationships.

Age of the plants also markedly affected enzyme action. Figure 2 illus- 
TABLE 9.-Mean protein content, and specific-activity values for leaf and meristem enzymes, of 16-month-old sugarcane grown on clay and sandy loam soils treated with Diuron ${ }^{1}$

\begin{tabular}{|c|c|c|c|c|c|c|c|c|c|c|}
\hline \multirow[b]{2}{*}{ Soil } & \multirow{2}{*}{$\begin{array}{c}\text { Diuron } \\
\text { (lb./acre) }\end{array}$} & \multicolumn{8}{|c|}{ Effects on leaf enzymes indicated } & \multirow{2}{*}{$\underset{\text { Mean }}{\text { Enzyme }}$} \\
\hline & & $\begin{array}{c}\text { Phos- } \\
\text { phatase }\end{array}$ & ATP-ase & G-1-P & Pase Amy & lase $\mid \begin{array}{c}P \\
p \\
o x\end{array}$ & \begin{tabular}{c|} 
Poly- \\
phenol \\
oxidase
\end{tabular} & $\begin{array}{l}\text { Peroxi- } \\
\text { dase }\end{array}$ & Proteinz & \\
\hline \multirow[t]{2}{*}{ Clay } & $\begin{array}{r}0 \\
2 \\
6 \\
18\end{array}$ & $\begin{array}{l}7.4 \\
7.8 \\
7.8 \\
9.6\end{array}$ & $\begin{array}{l}11.4 \\
11.5 \\
12.2 \\
13.9\end{array}$ & $\begin{array}{l}4 . \\
4 . \\
3 . \\
4 .\end{array}$ & $\begin{array}{l}1 \\
1 \\
9 \\
4\end{array}$ & $\begin{array}{l}7 \\
5 \\
5 \\
7\end{array}$ & $\begin{array}{l}2.9 \\
4.1 \\
3.2 \\
3.1\end{array}$ & $\begin{array}{l}43 \\
39 \\
36 \\
37\end{array}$ & $\begin{array}{l}4.0 \\
3.9 \\
4.0 \\
3.2\end{array}$ & $\begin{array}{l}19.3 \\
18.6 \\
19.7 \\
19.2\end{array}$ \\
\hline & Mean & 8.2 & 12.3 & 4 . & 1 & 9 & 3.3 & 39 & 3.8 & 19.2 \\
\hline \multirow[t]{4}{*}{$\begin{array}{l}\text { Sandy } \\
\text { loam }\end{array}$} & $\begin{array}{r}0 \\
2 \\
6 \\
18\end{array}$ & $\begin{array}{r}8.6 \\
12.0 \\
10.8 \\
10.1\end{array}$ & $\begin{array}{l}11.3 \\
14.2 \\
13.0 \\
12.6\end{array}$ & $\begin{array}{l}4 . \\
4 . \\
4 . \\
4 .\end{array}$ & $\begin{array}{l}3 \\
7 \\
5 \\
4\end{array}$ & $\begin{array}{l}8 \\
5 \\
5 \\
3\end{array}$ & $\begin{array}{l}4.3 \\
4.2 \\
3.7 \\
4.1\end{array}$ & $\begin{array}{l}37 \\
46 \\
51 \\
52\end{array}$ & $\begin{array}{l}3.6 \\
2.9 \\
2.9 \\
3.1\end{array}$ & $\begin{array}{l}20.6 \\
24.4 \\
21.3 \\
24.4\end{array}$ \\
\hline & Mean & 10.4 & 12.8 & 4 . & & 88 & 4.1 & 47 & 2.9 & 22.7 \\
\hline & & \multicolumn{8}{|c|}{ Effects on meristem enzymes indicated } & \\
\hline & & $\begin{array}{c}\text { Phos- } \\
\text { phatase }\end{array}$ & $\underset{\text { asc }}{\text { ATP- }}$ & $\begin{array}{l}\text { G-1- } \\
\text { Pase }\end{array}$ & Amylase & $\underset{\text { tase }}{\text { Inver- }}$ & $\mid \begin{array}{c}\text { Poly- } \\
\text { phenol } \\
\text { oxidase }\end{array}$ & $\begin{array}{c}\text { Peroxi- } \\
\text { dase }\end{array}$ & Protein'2 & \\
\hline \multirow[t]{2}{*}{ Clay } & $\begin{array}{r}0 \\
2 \\
6 \\
18\end{array}$ & $\begin{array}{l}10.3 \\
13.4 \\
10.5 \\
13.2\end{array}$ & $\begin{array}{l}11.5 \\
12.6 \\
11.0 \\
11.1\end{array}$ & $\begin{array}{l}6.4 \\
7.2 \\
6.3 \\
6.7\end{array}$ & $\begin{array}{l}79 \\
95 \\
79 \\
76\end{array}$ & $\begin{array}{l}6.6 \\
7.0 \\
6.9 \\
7.0\end{array}$ & $\begin{array}{l}29 \\
49 \\
25 \\
24\end{array}$ & $\begin{array}{r}85 \\
122 \\
86 \\
99\end{array}$ & $\begin{array}{l}23.3 \\
18.3 \\
21.3 \\
19.2\end{array}$ & $\begin{array}{l}32.5 \\
43.7 \\
32.1 \\
33.9\end{array}$ \\
\hline & Mean & 11.9 & 11.6 & 6.7 & 82 & 6.9 & 32 & 98 & 20.5 & 35.6 \\
\hline \multirow[t]{2}{*}{ Sandy } & $\begin{array}{r}0 \\
2 \\
6 \\
18\end{array}$ & $\begin{array}{l}12.4 \\
15.0 \\
14.3 \\
12.6\end{array}$ & $\begin{array}{l}11.1 \\
13.3 \\
13.4 \\
11.5\end{array}$ & $\begin{array}{l}5.3 \\
6.8 \\
6.4 \\
6.2\end{array}$ & $\begin{array}{l}74 \\
96 \\
83 \\
80\end{array}$ & $\begin{array}{l}7.5 \\
6.1 \\
5.3 \\
7.7\end{array}$ & $\begin{array}{l}22 \\
32 \\
36 \\
27\end{array}$ & $\begin{array}{l}69 \\
76 \\
80 \\
73\end{array}$ & $\begin{array}{l}22.5 \\
20.4 \\
20.1 \\
22.4\end{array}$ & $\begin{array}{l}28.8 \\
34.2 \\
34.1 \\
31.1\end{array}$ \\
\hline & Mean & 13.6 & 12.3 & 6.2 & 82 & 6.7 & 29 & 75 & 21.4 & 32.1 \\
\hline
\end{tabular}

1 Each figure represents the computed mean of 4 replicates.

Milligrams per gram of dry weight.

shorter intervals (3). But it should be remembered that the material harvested for enzymes, leaves +1 to +5 and meristem, is supposedly uniform, no matter what the age of the plant. Furthermore, the ratoon harvest taken at 16 months, representing 4 months of new growth, did not 
show amylase and ATP-ase revival to levels expected of "young" cane. Although little evidence is yet available, one might speculate that the degree of the canes' root development may determine foliar enzyme behavior rather than age of the foliage itself. Soil and age relationships with cane enzymology definitely need to be explored and promise excellent returns for the diligent investigator.

\section{SUMMARY}

Sugarcane was grown on Diuron-treated clay and sandy loam soils over a period of 16 months. There were three objectives: 1 , To evaluate Diuron
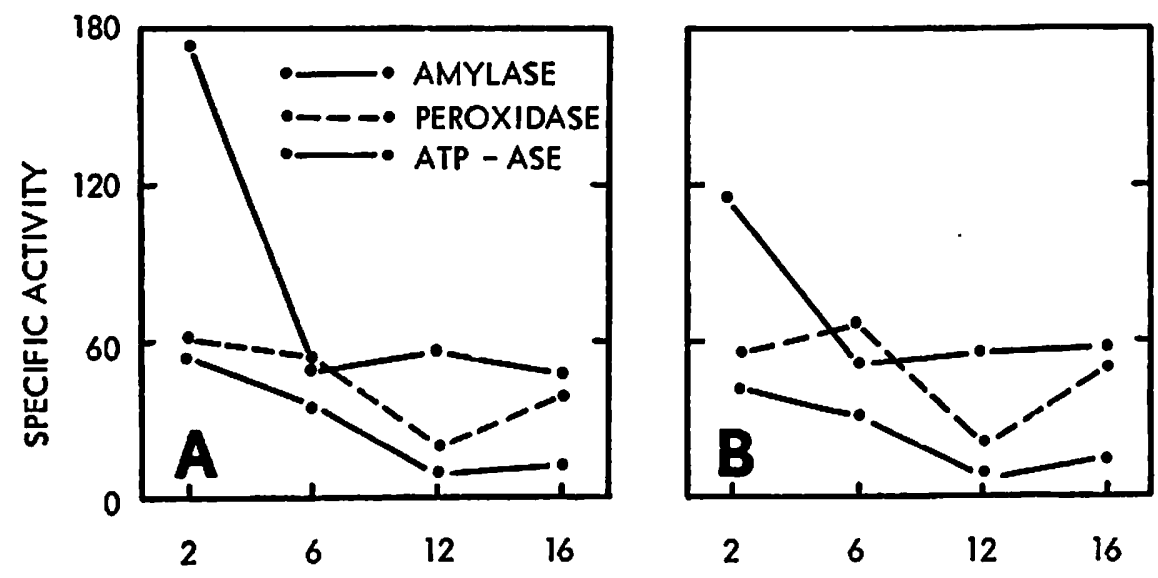

\section{AGE OF CANE (MONTHS)}

Fic. 2.-Effects of plant age on leaf-enzyme activity of sugarcane grown on Fajardo clay (A) and San Antón sandy loam (B).

effects upon sugar production; 2 , to determine Diuron effects upon enzymes over a prolonged period; 3 , to measure residual effects of Diuron on sugar production with variable soil types. The cane, grown in greenhouse soilbenches, was given water equivalent to about 75 inches per year. Diuron was applied to the soil as a pre-emergence spray at rates of $0,2,6$, and 18 pounds per acre. The following results were obtained:

1. Diuron severely suppressed sugar production by 2 -month-old plants. At 6 months the Diuron effect had lessened and it was no longer evident at 12 and 16 months.

2. Leaf analyses showed that Diuron absorption declined greatly after 2 months. By 16 months only traces of the herbicide were entering leaf tissues.

3. Diuron was far more readily absorbed from loam than from clay at 2 
months. At 16 months there was no detectable Diuron in leaf samples from loam, indicating a total exhaustion of the applied herbicide.

4. High Diuron absorption from loam was accompanied by a greater suppression of sugar in loam-produced samples than was evident with those from clay.

5. Soil type greatly affected the behavior of phosphatase, ATP-ase, amylase, invertase, peroxidase, and starch phosphorylase. None of the enzyme changes were consistent throughout the study, suggesting that the soil effects were indirect.

6. Diuron caused abnormal enzyme behavior throughout the study, but again the changes were inconsistent. It is theorized that the response of plants to initial Diuron action includes abnormal enzyme synthesis and synthesis of substances which block the sites of the herbicide's activity.

7. Enzyme activity generally declined as the plants grew older. First ratoon samples, representing 4 months of new growth, did not reveal activity comparable to the original 4-month-old material.

\section{RESUMEN}

Durante 16 meses y bajo condiciones de invernadero se cultivaron plantas de caña de azúcar en un suelo arcilloso y en otro francoarenoso, ambos tratados con Diurón. Este estudio tenía tres objectivos: 1, Evaluar los efectos del Diurón sobre la producción de azúcar; 2, determinar los efectos del Diurón sobre las enzimas por un período prolongado; 3 , medir los efectos residuales del Diurón sobre la producción de azúcar en varios tipos de suelos. Las plantas se regaron con un equivalente de alrededor de 75 pulgadas de lluvia al año. El Diurón se aplicó a los suelos en aspersiones preemergentes, a razón de 0, 2, 6 y 18 libras por acre.

Se obtuvieron los resultados siguientes:

1. El Diurón impidió marcadamente la producción de azúcar en las plantas de 2 meses de sembradas. El efecto disminuyó a los 6 meses y desapareció a los 12 y a los 16 meses.

2. Los análisis de la hoja indicaron que la absorción del Diurón disminuyó marcadamente después de 2 meses; y a los 16 , sólo rastros del yerbicida llegaban al tejido foliar.

3. A los 2 meses las plantas absorbieron el Diurón más fácilmente en el terreno franco que en el arcilloso. A los 16 meses las muestras de hojas tomadas del terreno franco no acusaron la presencia del Diurón, indicando así que se había extinguido totalmente el yerbicida aplicado.

4. La gran absorción del Diurón en el terreno franco fue acompañada de una supresión mayor del azúcar, en comparación con las muestras obtenidas en el arcilloso.

5. El tipo de suelo afectó marcadamente la actividad de la fosfatasa, la 
ATP-asa, la amilasa, la invertasa, la peroxidasa y la fosforilasa del almidón. Ninguno de los cambios en las enzimas fue consistente, lo que sugirió que los efectos debidos al tipo de suelo eran indirectos.

6. El Diurón causó reacciones anormales en las enzimas, pero, también, los cambios eran inconsistentes. La teoría es que la reacción de la planta a la acción inicial del Diurón incluye la síntesis anormal de las enzimas y la de las substancias que bloquean los puntos en que actúa el yerbicida.

7. En términos generales, la actividad enzimática disminuyó según la edad de las plantas. Las muestras del primer retoño, que representan 4 meses de crecimiento nuevo, no indicaron una actividad comparable a la obtenida en el material original a los 4 meses de edad.

\section{LITERATURE CITED}

1. Alexander, A. G., and González Ibánez, J., Residual effects of Diuron [3-(3,4dichlorophenyl)-1,1-dimethylurea] on the sugar content and sugar metabolizing enzymes of ratoon sugarcane 25 months following different soil treatment, $J$. Agr. Univ. P.R. 48 (4): 284-303, 1964.

2. Alexander, A. G., In vitro effects of Diuron [3-(4-dichlorophenyl)-1,1-dimethylurea] upon enzymes catalyzing the synthesis and hydrolisis of sucrose, starch, and phosphorylated hexose in sugarcane. Proc. Intnl. Soc. Sugarcane Tech. pp. 582-9, 1965. (In press).

3. - Sucrose-enzyme relationships in immature sugarcane as affected by varying levels of nitrate and potassium in sand culture, J. Agr. Univ. P.R. 48 (3): 165-231, 1964.

4. - Hydrolytic proteins of sugarcane: The acid phosphatases, J. Agr. Univ. P.R. 49 (2): 204-28, 1965.

5. - - Hydrolytic proteins of sugarcane: Invertase, J. Agr. Univ. P.R. 49 (3): 287-307, 1965.

6. - Hydrolytic proteins of sugarcane: Amylase, J. Agr. Univ. P.R. 49 (2): 204-28, 1965.

7. - Oxidizing enzymes of sugarcane: Peroxidase, J. Agr. Univ. P.R. 50 (1): 36-52, 1966.

8. - Oxidizing enzymes of sugarcane: Tryosinase, J. Agr. Univ. P.R. 50 (2): 113-130, 1966.

9. - The biosynthesis of starch in sugarcane, Proc. Intl. Soc. Sugarcane Tech., XII Cong. San Juan, P.R. pp. 626-38, 1965.

10. - Effects of variable Diuron and nitrate on sucrose content plus enzyme activity of sugarcane grown in sand culture, J. Agr. Univ. P.R. (In press).

11. Cardini, C. E., Leloir, L. F., and Chiriboga, J., The biosynthesis of sucrose, $J$. Biol. Chem. 214: 149-55, 1955.

12. Cooke, A. R., A possible mechanism of action of the urea type herbicides, Weeds 4 (4): 397-8, 1956.

13. Gentner, W. A., and Hilton, J. L., Weed Soc. Amer., 1960 meeting, abstracts, February, p. 32.

14. Hilton, J. L., Effect of histidine on the inhibitory action of 3-amino-1,2,4triazole, Weeds \& (3): 39-46, 1960.

15. Jagendorf, A. T., The relationship between electron transport and phosphoryla- 
DIURON, SUGAR PRODUCTION, AND ENZYME ACTIVITY OF SUGARCANE 139

tion in spinach chloroplasts, Brookhaven Symposium in Biology, No. 11, 236-58, 1958.

16. Roe, J. R., A colorimetric method for the determination of fructose in blood and urine, J. Biol. Chem. 107: 15-22, 1934.

17. Sutherland, E. W., Cori, C. F., Haynes, R., and Olsen, N. S., Purification of the hyperglycemic-glycogenolytic factor from insulin and from gastric muscosa, $J$. Biol. Chem. 180: 825-37, 1949.

18. Wessels, J. S. C. and Van der Veen, R., Action of some derivatives of phenylurethan and of 3-phenyl-1,1-dimethylurea on the Hill reaction, Biochem. et Biophys. Acta. 19: 548-9, 1956.

19. Young, H. Y., and Gortner, W. A., Microdetermination of 3-(p-chlorophenyl)1,1-dimethylurea in plant tissue, Anal. Chem. 25: 800-2, 1953. 